Table. Efficiency analysis

\begin{tabular}{|c|c|c|c|c|c|c|c|c|}
\hline & & & Version 1 & (Pallets) & Version 2 & (Shelves) & Version 3 & $\begin{array}{l}\text { (Rotating } \\
\text { Shelf) }\end{array}$ \\
\hline Objective & Description & Weight & $\begin{array}{l}\text { Degree of } \\
\text { Achievement }\end{array}$ & $\begin{array}{l}\text { Weight times } \\
\text { Achievement }\end{array}$ & $\begin{array}{l}\text { Degree of } \\
\text { Achievement }\end{array}$ & $\begin{array}{l}\text { Weight times } \\
\text { Achievement }\end{array}$ & $\begin{array}{l}\text { Degree of } \\
\text { Achievement }\end{array}$ & $\begin{array}{l}\text { Weight times } \\
\text { Achievement }\end{array}$ \\
\hline $\begin{array}{l}M \\
M\end{array}$ & $\begin{array}{l}\text { Cheese quality } \\
\text { Hygiene / } \\
\text { Contamination }\end{array}$ & & $\begin{array}{l}\text { yes } \\
\text { yes }\end{array}$ & & $\begin{array}{l}\text { yes } \\
\text { yes }\end{array}$ & & $\begin{array}{l}\text { yes } \\
\text { yes }\end{array}$ & \\
\hline $\begin{array}{l}\mathrm{M} / \mathrm{W} \\
\mathrm{M} / \mathrm{W}\end{array}$ & $\begin{array}{l}\text { Costs } \\
\text { Implementation }\end{array}$ & 2 & 8 & 16 & 6 & 12 & 2 & 4 \\
\hline w & time & 1 & 5 & 5 & 3 & 3 & 7 & 7 \\
\hline W & $\begin{array}{l}\text { expenditure } \\
\text { Increased } \\
\text { capacity }\end{array}$ & 2 & 0 & 10 & 2 & 2 & 10 & 10 \\
\hline Total numb & er of points & & & 31 & & 19 & & 27 \\
\hline
\end{tabular}

\title{
Optimising the Addition of Transglutaminase in the Preparation of Sour Milk Products [1]
}

\author{
Lukas Wieland $^{\mathrm{a}}$, Elisabeth Eugster ${ }^{\mathrm{a}}$, and Pius Eberhard ${ }^{\mathrm{b}}$
}

Abstract: The addition of transglutaminase in yoghurt production was examined in a diploma thesis. In comparison to the control sample, it was possible to reduce the thermal treatment of the yoghurt milk and to entirely eliminate the addition of skim milk powder. The resulting product showed a high gel strength and only slight whey separation. The incubation temperature proved to be an important factor for success.

Keywords: Gel formation · Sensory evaluation · Transglutaminase · Yoghurt production

${ }^{\star}$ Correspondence: Dr. E. Eugstera aswiss College of Agriculture Länggasse 85

$\mathrm{CH}-3052$ Zollikofen

E-Mail: elisabeth.eugster@shl.bhf.ch

${ }^{\mathrm{b}}$ Swiss Dairy Research Station, Bern-Liebefeld
Transglutaminase (TG) is an enzyme which crosslinks protein at the side chains of the amino acids lysine and glutamic acid, resulting in protein polymerization (Fig. 1). Not only does the addition of TG change the rheological properties of a sour milk product, but the enzyme also has a considerable influence on its organoleptic properties, syneresis and the acidifying process.

An initial experiment clarified how far the TG can lower heating temperatures and reduce the quantity of added skim milk powder (SMP). The first experiment showed that a product very similar to the control sample ( $\left.1 \% \mathrm{SMP}, 92{ }^{\circ} \mathrm{C} / 5 \mathrm{~min}\right)$ is produced by heating at a temperature of $85^{\circ} \mathrm{C}$ for 5 min without adding skim milk powder, but rather $17.5 \mathrm{U} \mathrm{TG} / \mathrm{kg}$ of yoghurt milk (Fig. 2). In general, the addition of TG in the first experiment led to a higher gel strength, with a tendency towards less whey drainage and shorter incubation times. The TG also changed the organoleptic properties of the yoghurt. The testers judged the 
Table. Efficiency analysis

\begin{tabular}{|c|c|c|c|c|c|c|c|c|}
\hline & & & Version 1 & (Pallets) & Version 2 & (Shelves) & Version 3 & $\begin{array}{l}\text { (Rotating } \\
\text { Shelf) }\end{array}$ \\
\hline Objective & Description & Weight & $\begin{array}{l}\text { Degree of } \\
\text { Achievement }\end{array}$ & $\begin{array}{l}\text { Weight times } \\
\text { Achievement }\end{array}$ & $\begin{array}{l}\text { Degree of } \\
\text { Achievement }\end{array}$ & $\begin{array}{l}\text { Weight times } \\
\text { Achievement }\end{array}$ & $\begin{array}{l}\text { Degree of } \\
\text { Achievement }\end{array}$ & $\begin{array}{l}\text { Weight times } \\
\text { Achievement }\end{array}$ \\
\hline $\begin{array}{l}M \\
M\end{array}$ & $\begin{array}{l}\text { Cheese quality } \\
\text { Hygiene / } \\
\text { Contamination }\end{array}$ & & $\begin{array}{l}\text { yes } \\
\text { yes }\end{array}$ & & $\begin{array}{l}\text { yes } \\
\text { yes }\end{array}$ & & $\begin{array}{l}\text { yes } \\
\text { yes }\end{array}$ & \\
\hline $\begin{array}{l}\mathrm{M} / \mathrm{W} \\
\mathrm{M} / \mathrm{W}\end{array}$ & $\begin{array}{l}\text { Costs } \\
\text { Implementation }\end{array}$ & 2 & 8 & 16 & 6 & 12 & 2 & 4 \\
\hline w & time & 1 & 5 & 5 & 3 & 3 & 7 & 7 \\
\hline W & $\begin{array}{l}\text { expenditure } \\
\text { Increased } \\
\text { capacity }\end{array}$ & 2 & 0 & 10 & 2 & 2 & 10 & 10 \\
\hline Total numb & er of points & & & 31 & & 19 & & 27 \\
\hline
\end{tabular}

\title{
Optimising the Addition of Transglutaminase in the Preparation of Sour Milk Products [1]
}

\author{
Lukas Wieland $^{\mathrm{a}}$, Elisabeth Eugster ${ }^{\mathrm{a}}$, and Pius Eberhard ${ }^{\mathrm{b}}$
}

Abstract: The addition of transglutaminase in yoghurt production was examined in a diploma thesis. In comparison to the control sample, it was possible to reduce the thermal treatment of the yoghurt milk and to entirely eliminate the addition of skim milk powder. The resulting product showed a high gel strength and only slight whey separation. The incubation temperature proved to be an important factor for success.

Keywords: Gel formation · Sensory evaluation · Transglutaminase · Yoghurt production

${ }^{\star}$ Correspondence: Dr. E. Eugstera aswiss College of Agriculture Länggasse 85

$\mathrm{CH}-3052$ Zollikofen

E-Mail: elisabeth.eugster@shl.bhf.ch

${ }^{\mathrm{b}}$ Swiss Dairy Research Station, Bern-Liebefeld
Transglutaminase (TG) is an enzyme which crosslinks protein at the side chains of the amino acids lysine and glutamic acid, resulting in protein polymerization (Fig. 1). Not only does the addition of TG change the rheological properties of a sour milk product, but the enzyme also has a considerable influence on its organoleptic properties, syneresis and the acidifying process.

An initial experiment clarified how far the TG can lower heating temperatures and reduce the quantity of added skim milk powder (SMP). The first experiment showed that a product very similar to the control sample ( $\left.1 \% \mathrm{SMP}, 92{ }^{\circ} \mathrm{C} / 5 \mathrm{~min}\right)$ is produced by heating at a temperature of $85^{\circ} \mathrm{C}$ for 5 min without adding skim milk powder, but rather $17.5 \mathrm{U} \mathrm{TG} / \mathrm{kg}$ of yoghurt milk (Fig. 2). In general, the addition of TG in the first experiment led to a higher gel strength, with a tendency towards less whey drainage and shorter incubation times. The TG also changed the organoleptic properties of the yoghurt. The testers judged the 


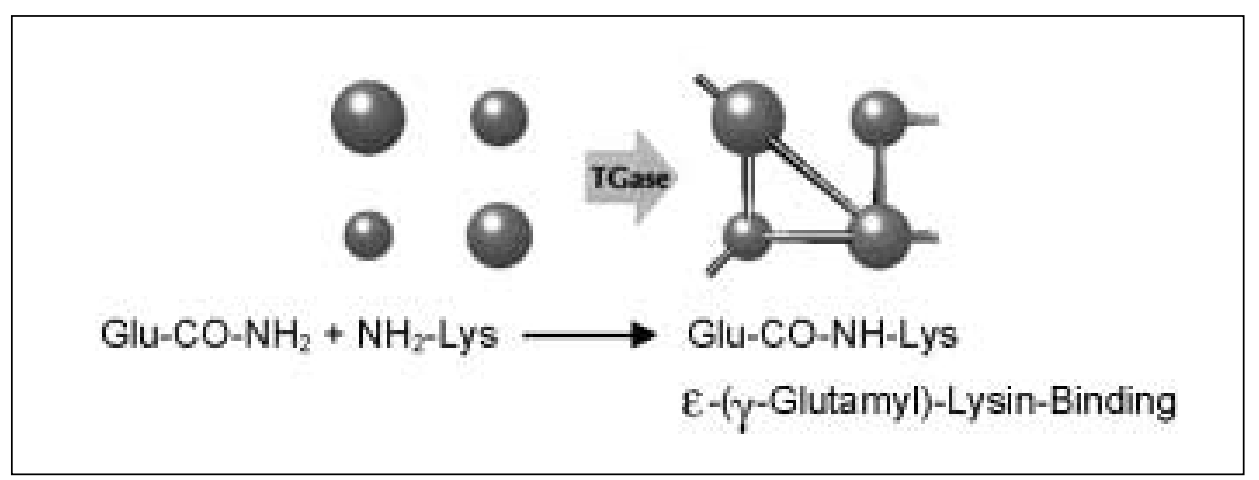

Fig. 1. How transglutaminase (TG) functions

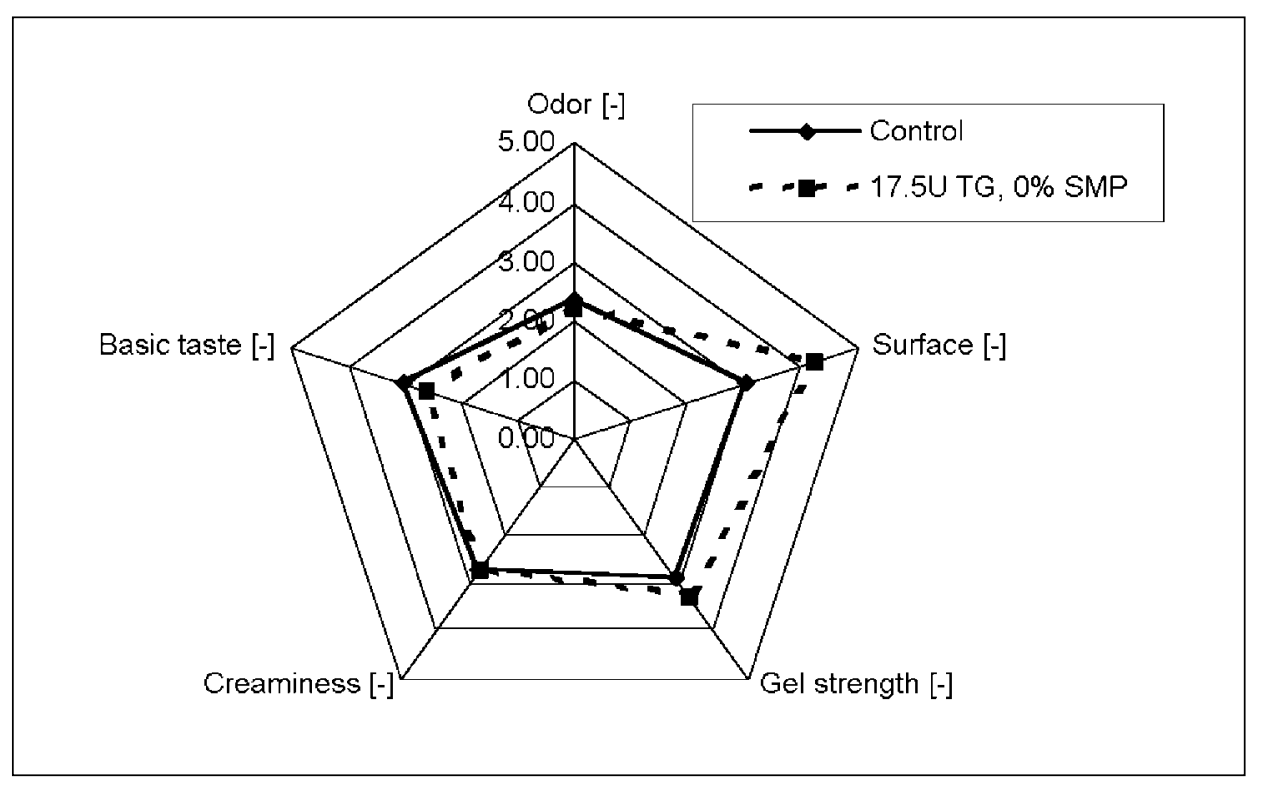

Fig. 2. A comparison of sensory attributes between the control sample ( $\left.1 \% \mathrm{SMP}, 92^{\circ} \mathrm{C} / 5 \mathrm{~min}\right)$ and a product treated with enzyme (17.5U TG, $\left.0 \% \mathrm{SMP}, 85^{\circ} \mathrm{C} / 5 \mathrm{~min}\right)$. Odour: $1=$ weak, 5 = strong; Surface: 1 = dull, 5 = shiny; Gel strength: 1 = soft, 5 = firm; Creaminess: 1 = not very creamy, 5 = very creamy; Basic taste: 1 = slightly sour, 5 = very sour.

intensity of odor and taste of the yoghurt to be less strong. They noticed a shinier surface and a significantly firmer consistency than the control sample.

Up to now trials have always involved TG incubation of the yoghurt milk at $40{ }^{\circ} \mathrm{C}$. The producer indicated that the enzyme reaction can also occur at $5{ }^{\circ} \mathrm{C}$. Therefore a second test was dedicated to optimising the production process. The incubation of the yoghurt milk with TG was carried out at cooling temperatures of $5{ }^{\circ} \mathrm{C}$ for $16 \mathrm{~h}$. The yoghurt milk was then heated at $80{ }^{\circ} \mathrm{C} / 1$ min only. This resulted in a slightly reduced gel strength and heavier whey drainage. In order to obtain firmer gel consistencies and lighter whey drainage at lower incubationand higher heating temperatures, further tests must be made.
Whether or not the addition of TG has a future in the production of sour milk products in Switzerland does not depend solely on technological aspects, but also on legal aspects. The addition of TG still requires authorisation from the Swiss Department of Health (BAG) and if enzymes are added, this must be declared on the package.

Received: May 2, 2002

[1] L. Wieland, 'Optimising the Addition of Transglutaminase in the Preparation of Sour Milk Products', Diploma Thesis, Swiss College of Agriculture, Zollikofen, 2001. 